\title{
Internal carotid artery dissection due to elongated styloid process
}

\author{
Matthew Tanti @ (, Aubrey Smith, ${ }^{2}$ Daniel J Warren, ${ }^{3}$ Luis Idrovo ${ }^{1}$
}

'Department of Neurology, Leeds Teaching Hospitals NHS Trust, Leeds, UK

${ }^{2}$ Department of Neuroradiology, Hull Royal Infirmary, Hull, UK ${ }^{3}$ Department of Radiology, Leeds Teaching Hospitals NHS Trust, Leeds, UK

\section{Correspondence to}

Dr Matthew Tanti;

m.tanti@nhs.net

Accepted 24 August 2021

\section{DESCRIPTION}

A young student was resistance training at the gym when he developed a headache and collapsed. On waking, there was left-sided facial weakness, visual extinction and sensory loss. Investigations revealed a right internal carotid artery dissection (ICAD) and M1 thrombus. Intravenous thrombolysis was given, but he deteriorated (National Institutes of Health Stroke Scale, 14 to 20). He was referred to interventional radiology and successfully treated with mechanical clot retrieval and ICAD stenting (figure 1). A right frontal lobe infarct was evident on CT (figure 2). Dual antiplatelets were prescribed for 3 months followed by lifelong single antiplatelet. He had no stroke risk factors or medical history. On reviewing his CT images, bilateral elongated styloid processes (ESP) were identified; $7.4 \mathrm{~cm}$ for the right and $7.0 \mathrm{~cm}$ for the left (normal less than $3 \mathrm{~cm}$ ) (figure 1). The patient declined stylectomy, but he made a full recovery and the only problem at 3 years is low mood.

An elongated styloid process, which can include a calcified stylohyoid ligament, does not usually cause symptoms. ${ }^{1}$ Rarely, some develop pain due to contact with neurovascular structures in what is known as Eagle syndrome after the otolaryngologist describing it in $1937 .^{2}$ Our patient never had symptoms of Eagle syndrome. ICAD due to ESP is rare, but well described. ${ }^{34}$ Some authors have identified ESP length or ESP angulation and carotid artery proximity as being important risk factors for ICAD, but others have
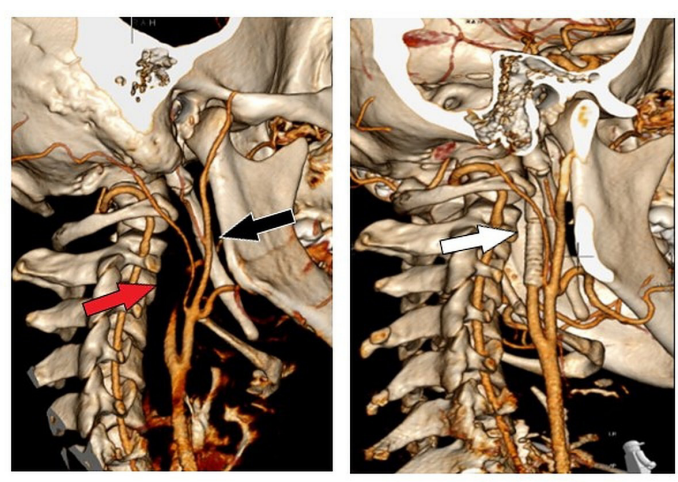

Limited 2021. No commercia re-use. See rights and permissions. Published by BMJ.

To cite: Tanti M, Smith A, Warren DJ, et al. BMJ Case Rep 2021;14:e245908 doi:10.1136/bcr-2021245908
Figure 1 Left: reconstructed CT image demonstrating absence of flow in right internal carotid artery (red arrow) and right-sided elongated styloid process which has two pseudoarticulations (black arrow). Right: Postprocedure reconstructed image demonstrating stent adjacent to styloid process (white arrow).

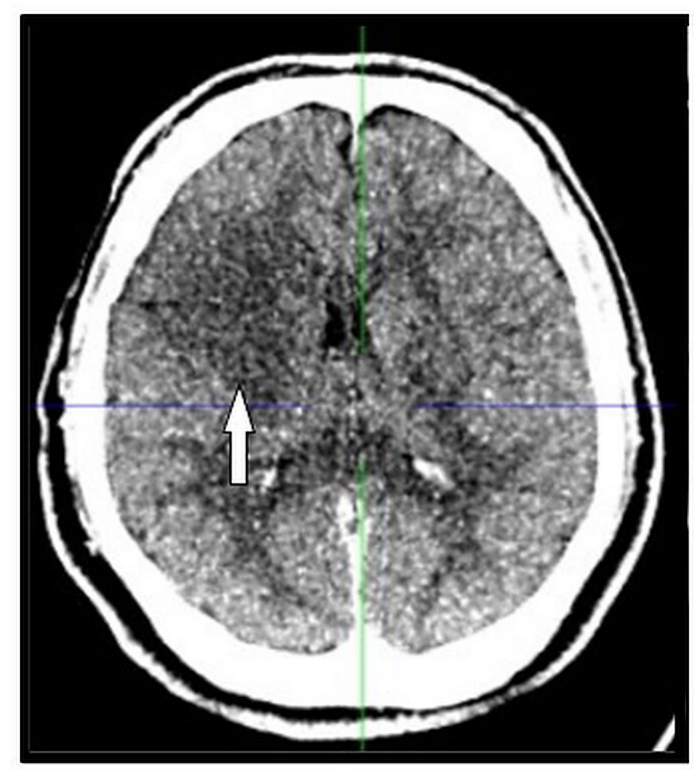

Figure 2 Head CT demonstrating evolving infarction of right frontal lobe (white arrow).

demonstrated that these factors have no relation. ${ }^{5-7}$ Triggering events like exercise and neck massage are commonly seen, but most are spontaneous. $^{34}$ The initial treatment of ICAD due to ESP resembles that of ICAD and stroke, with many authors opting for medical management with or without early endovascular intervention. $^{34}$ Like our patient, many with ICAD due to ESP have early deterioration despite medical management, so they should be monitored with a low threshold for referral to interventional radiology or otolaryngology. Definitive treatment of Eagle syndrome is resection, but the role of ESP resection for ICAD is unclear. ${ }^{8}$ Late complications can occur in patients without ESP resection, namely recurrent stroke, carotid stent fracture, persistent ICA stenosis with dissection flap, stent displacement and pseudoaneurysm formation, so stylectomy or delayed imaging should be considered. ${ }^{9-12}$

Contributors MT composed the manuscript. LI directed the project. AS and DJW were responsible for interpreting imaging. All authors were involved in the design and review of the manuscript and the literature.

Funding The authors have not declared a specific grant for this research from any funding agency in the public, commercial or not-for-profit sectors.

Competing interests None declared.

Patient consent for publication Obtained. 


\section{Learning points}

Dissection is a common cause of ischaemic stroke in young patients.

- In patients with spontaneous or low energy dissection, review images for an elongated styloid process.

- Consider monitoring in these patients as early and late deterioration is reported.

Provenance and peer review Not commissioned; externally peer-reviewed.

\section{ORCID iD}

Matthew Tanti http://orcid.org/0000-0002-8258-9634

\section{REFERENCES}

1 Gokce C, Sisman Y, Sipahioglu M. Styloid process elongation or Eagle's syndrome: is there any role for ectopic calcification? Eur J Dent 2008;2:224-8.

2 Eagle WW. Elongated styloid processes: report of two cases. Arch Otolaryngol 1937;25:584-7.
3 Zammit M, Chircop C, Attard V, et al. Eagle's syndrome: a piercing matter. BMJ Case Rep 2018;11:e226611-6.

4 Ogura T, Mineharu Y, Todo K, et al. Carotid artery dissection caused by an elongated styloid process: three case reports and review of the literature. NMC Case Rep J 2015;2:21-5.

5 Raser JM, Mullen MT, Kasner SE, et al. Cervical carotid artery dissection is associated with styloid process length. Neurology 2011;77:2061-6.

6 Tardivo V, Castaldi A, Baldino G, et al. Internal carotid artery dissection related to abnormalities of styloid process: is it only a matter of length? Neurol Sci 2021. doi:10.1007/s10072-021-05350-8. [Epub ahead of print: 31 May 2021].

7 Cruddas L, Joffe M, Baker D. Can styloid process and internal carotid artery anatomy be used to predict carotid artery dissection? Ann Vasc Surg 2021;74:105-10.

8 Ceylan A, Köybaşioğlu A, Çelenk F, et al. Surgical treatment of elongated styloid process: experience of 61 cases. Skull Base 2008;18:289-95.

9 Sveinsson 0, Kostulas N, Herrman L. Internal carotid dissection caused by an elongated styloid process (Eagle syndrome). BMJ Case Rep 2013:2-5.

10 Hooker JD, Joyner DA, Farley EP, et al. Carotid stent fracture from Stylocarotid syndrome. J Radiol Case Rep 2016;10:1-8.

11 Mann A, Kujath S, Friedell ML, et al. Eagle syndrome presenting after blunt trauma. Ann Vasc Surg 2017;40:295.e5-295.e8.

12 Shimozato R, Hayashi M, Niimura M, et al. Two patients with cerebral infarction who underwent endovascular treatment for internal carotid artery dissection related to an elongated styloid process. Noushinkei Kekkannai Tiryou 2018;12:355-61.

Copyright 2021 BMJ Publishing Group. All rights reserved. For permission to reuse any of this content visit

https://www.bmj.com/company/products-services/rights-and-licensing/permissions/

BMJ Case Report Fellows may re-use this article for personal use and teaching without any further permission.

Become a Fellow of BMJ Case Reports today and you can:

- Submit as many cases as you like

- Enjoy fast sympathetic peer review and rapid publication of accepted articles

- Access all the published articles

- Re-use any of the published material for personal use and teaching without further permission

Customer Service

If you have any further queries about your subscription, please contact our customer services team on +44 (0) 2071111105 or via email at support@bmj.com.

Visit casereports.bmj.com for more articles like this and to become a Fellow 